Огляди літератури, оригінальні дослідження, погляд на проблему, випадок з практики, короткі повідомлення УДК 616-002.5-06:616.98: 089

DOI 10.11603/1811-2471.2020.v.i1.11077

\title{
АНАЛІЗ ХІРУРГІЧНОГО ЛІКУВАННЯ ХВОРИХ НА ТУБЕРКУЛЬОЗНУ ЕМПІЕМУ ПЛЕВРИ
}

๑ю. Ф. Кошак

\section{Тернопільський національний медичний університет імені І. Я. Горбачевського МОЗ України}

РЕзюМЕ. Мета - покращити результати малоінвазивного хірургічного лікування хворих із туберкульозною емпіємою плеври.

Матеріал і методи. Проведений ретроспективний аналіз 685 випадків туберкульозної емпієми плеври у пацієнтів, які за останні 10 років отримали стаціонарне лікування у фтизіохірургічному відділенні Тернопільського обласного протитуберкульозного диспансеру. Усім хворим були проведені необхідні клінічні, лабораторні та інструментальні дослідження, включаючи рентгенологічні та імунологічні методи обстеження.

Результати. Представлено перший в Україні аналіз результатів хірургічного лікування хворих на туберкульозну емпієму плеври залежно від застосування стандартних діагностичних та хірургічних методик. Проаналізовано морфологічні особливості стадійності, локалізації та діагностики туберкульозної емпієми плеври залежно від статі, віку, початку, перебігу та поширеності нагноєння. Аналіз діагностичної цінності стандартних методів діагностики туберкульозного нагноєння у хворих на туберкульоз показав, що своєчасне виявлення такого ускладнення значно утруднене. Найбільші діагностичні труднощі трапляються у пацієнтів із локалізацією емпієми плеври в зоні активних туберкульозних або метатуберкульозних змін.

Висновки. Показано провідний вплив виду туберкульозного ураження плеври на оперативне лікування хворих на туберкульозну емпієму плеври та шляхи покращення хірургічних методик до малоінвазивного торакохірургічного лікування.

КлючОВІ СлОВА: туберкульоз; туберкульозна емпієма плеври; відеоторакоскопія; відеоасистована хірургічна резекція; відкрита плевректомія з декортикацією легені.

Вступ. За даними ВООЗ, через формування резистентності мікроорганізмів змішаної специфічної та неспецифічної флори до ряду груп основних антибіотиків, у цілому світі спостерігається поява гнійних захворювань із суперінфекцією. 3 метою аналізу результатів хірургічного лікування хворих на туберкульозну емпієму плеври (ТЕП) ми провели клінічну оцінку стандартних діагностичних методик, спрямованих на етіологічне виявлення емпієми плеври у хворих на туберкульоз (ТБ). Нагноєння плеври пов'язані насамперед із невстановленою причиною ускладнень різноманітних за етіопатогенезом захворювань: 1) специфічні (туберкульоз, гнійні плеврити, набутий імунодефіцит, ВІЛ-інфекція), 2) неспецифічні (парапневмонічні, параканкрозні, септичні), 3) посттравматичні (згорнуті гемо- та пневмоторакси), 4) застійні (серцеві, післяопераційні) тощо. Низький рівень сучасної діагностики туберкульозної емпієми плеври за наведеними вище категоріями призводить до зростання захворюваності на ТБ. Раціональний вибір діагностики та комбінованого хірургічного втручання значно зменшує формування резистентності нагноєння при туберкульозній емпіємі плеври. Проаналізовано морфологічні особливості туберкульозної емпієми плеври та вплив активного туберкульозу на результати хірургічного лікування. При вивченні впливу туберкульозного нагноєння на хід виконання стандартних хірургічних втручань (плевректомія з декортикацією легені) у хворих встановлено, що облітерація плевральної порожнини, фіброзно-склеротична деформація легене- вої паренхіми та нагноєння залишкової плевральної порожнини створюють технічні труднощі у встановленні етіологічної причини туберкульозного ураження плеври, яке згодом унеможливлює малоінвазивне проведення плевректомії з декортикацією легені (ПЕ з ДЛ). Усе це призводить до латентного перебігу туберкульозного нагноєння плеври, хронізації процесу та інвалідизації хворого, що $€$ актуальними в торакальній хірургії.

Мета - покращити результати малоінвазивного хірургічного лікування хворих із туберкульозною емпіємою плеври шляхом аналізу причин незадовільної діагностики та хірургічного лікування з використанням стандартних методів.

Матеріал і методи дослідження. Проведений ретроспективний аналіз 685 випадків туберкульозної емпієми плеври у пацієнтів, які за останні 10 років пройшли стаціонарне лікування у фтизіохірургічному відділенні Тернопільського обласного протитуберкульозного диспансеру. Усім хворим були проведені необхідні клінічні, лабораторні та інструментальні дослідження, включаючи рентгенологічні та імунологічні методи обстеження. При аналізі діагностичних алгоритмів нами були виділені їх основні групи, які дозволили провести діагностику появи туберкульозної емпієми плеври залежності від початку захворювання, статті, віку хворого, локалізації та поширеності туберкульозного процесу.

Прооперованих хворих було поділено на дві групи: основна група - 351 (51,25 \%) пацієнт, якого було прооперовано із застосуванням малоінвазив- 
Огляди літератури, оригінальні дослідження, погляд на проблему, випадок з практики, короткі повідомлення них технологій (VTS, VATS); група порівняння $334(48,75 \%)$ хворих, яких було прооперовано відкритою боковою торакотомією (ПЕ з ДЛ). Із 351 пацієнта основної групи у 301 діагностовано гостру туберкульозну емпієму плеври, у 50 - хронічну. Серед пацієнтів групи порівняння гостра емпієма плеври встановлена у 284 хворих, хронічна -у 50.

Результати й обговорення.

За нашими даними лише відеоторакоскопія (VTS) $є$ високоінформативним методом діагностики плевральних випотів, виявлення туберкульозної емпієми плеври на першій, другій та третій стадіях їі розвитку, результати ТЕП представлено в таблиці 1.

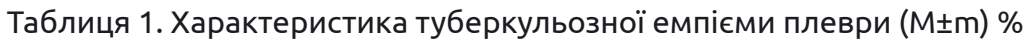

\begin{tabular}{|c|c|c|c|c|}
\hline \multirow{2}{*}{$\begin{array}{c}\text { Показник } \\
\text { туберкульозного процесу }\end{array}$} & \multicolumn{2}{|c|}{$\begin{array}{c}\text { Основна група, } \\
\mathrm{n}=351\end{array}$} & \multicolumn{2}{|c|}{$\begin{array}{c}\text { Група порівняння, } \\
\text { n=334 }\end{array}$} \\
\hline & a6c. & $(M \pm m) \%$ & a6c. & $(M \pm m) \%$ \\
\hline Гостра ТЕП & 301 & $85,7 \pm 1,3 *$ & 284 & $85,0 \pm 1,7 *$ \\
\hline Хронічна ТЕП & 50 & $14,2 \pm 0,3$ * & 50 & $14,9 \pm 0,3 *$ \\
\hline
\end{tabular}

Примітка. *-достовірна різниця між групами $(p<0,05)$.

Наведені дані дозволяють стверджувати, що більшості хворих на туберкульозну емпієму плеври діагноз встановлюють у гострій I-ІІ стадії захворювання. У результаті погрішностей в консер- вативному лікуванні цей процес переходить в періодично прогресуючий хронічний перебіг ТЕП.

Розподіл пацієнтів обох груп дослідження за статевою ознакою показано в таблиці 2.

Таблиця 2. Розподіл пацієнтів за статтю $(\mathrm{M} \pm \mathrm{m}) \%$

\begin{tabular}{|l|c|c|c|c|}
\hline \multirow{2}{*}{ Стать } & \multicolumn{2}{|c|}{ Основна група } & \multicolumn{2}{c|}{ Група порівняння } \\
\cline { 2 - 5 } & а6с. & $(\mathrm{M} \pm \mathrm{m}) \%$ & a6c. & $(\mathrm{M} \pm \mathrm{m}) \%$ \\
\hline Чоловіків & 264 & $75,2 \pm 1,3^{*}$ & 254 & $76,1 \pm 1,7^{*}$ \\
\hline Жінок & 87 & $24,7 \pm 0,3^{*}$ & 80 & $23,9 \pm 2,2^{*}$ \\
\hline Всього & 351 & $100 \% *$ & 334 & $100 \% *$ \\
\hline
\end{tabular}

Примітка. * - достовірна різниця між групами $(p<0,05)$.

Більшість пацієнтів із туберкульозною емпіємою плеври становили чоловіки 75,2 - 76,0 \%, натомість жінки склали 23,9 - 24,0 \% випадків.

Розподіл вікових груп пацієнтів наведено в таблиці 3.

Аналіз показав, що в наших дослідженнях вік хворих коливався від 18 до 80 років. Кількість па- цієнтів працездатного віку, до 60 років, становила в основній групі 80,9\%, в порівняльній -81,8\%. Максимальна кількість хворих обох груп була вікової категорії 31-70 років. Тенденція до збільшення пацієнтів старшого віку потребує подальшого вивчення з урахуванням вікових особливостей та наявної супутньої патології.

Таблиця 3. Розподіл пацієнтів за віком $(\mathrm{M} \pm \mathrm{m}) \%$

\begin{tabular}{|c|c|c|c|c|}
\hline \multirow{2}{*}{ Вік пацієнтів } & \multicolumn{2}{|c|}{ Основна група $(n=351)$} & \multicolumn{2}{|c|}{ Група порівняння (n=334) } \\
\hline & a6c. & $(M \pm m) \%$ & a6c. & $(M \pm m) \%$ \\
\hline $18-20$ & 16 & $4,5 \pm 0,3 *$ & 4 & $1,8 \pm 0,7$ * \\
\hline $21-30$ & 29 & $8,2 \pm 0,6 *$ & 28 & $8,3 \pm 0,8^{*}$ \\
\hline $31-40$ & 65 & $18,5 \pm 2,3^{*}$ & 58 & $17,3 \pm 2,2^{*}$ \\
\hline $41-50$ & 92 & $26,2 \pm 2,1 *$ & 93 & $27,8 \pm 3,2 *$ \\
\hline $51-60$ & 82 & $23,3 \pm 0,7^{*}$ & 89 & $26,6 \pm 1,3 *$ \\
\hline $61-70$ & 53 & $15,0 \pm 3,6^{*}$ & 51 & $15,2 \pm 2,8 *$ \\
\hline $71-80$ & 14 & $3,9 \pm 0,6^{*}$ & 15 & $4,4 \pm 1,3^{*}$ \\
\hline Всього & 351 & $100 \% *$ & 334 & $100 \% *$ \\
\hline
\end{tabular}

Примітка. * - достовірна різниця між групами $(p<0,05)$.

У результаті аналізу дослідження виявлено, що в обох групах переважали хворі із емпіємою плеври при легеневому туберкульозі та фібри- нозному туберкульозному плевриті, який ускладнився нагноєнням плеври. В основній групі вони разом склали 79,48 \%, а в порівняльній - 82,03 \% 
Огляди літератури, оригінальні дослідження, погляд на проблему, випадок з практики, короткі повідомлення випадків. Наявність в обох групах пацієнтів із посттравматичною емпіємою, змішаними та післяопераційними нагноєннями вказує на неефективність консервативного лікування, що прово-

дилося на попередніх етапах. Розподіл пацієнтів обох груп із туберкульозною емпіємою плеври залежно від етіології збудника представлено в таблиці 4.

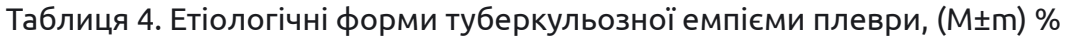

\begin{tabular}{|l|c|c|c|c|}
\hline \multirow{2}{*}{$\begin{array}{c}\text { Форма туберкульозної емпієми } \\
\text { плеври }\end{array}$} & \multicolumn{2}{|c|}{ Основна група } & \multicolumn{2}{c|}{ Група порівняня } \\
\cline { 2 - 5 } & абс. & $(\mathrm{M} \pm \mathrm{m}) \%$ & $\mathrm{a6c.}$ & $(\mathrm{M} \pm \mathrm{m}) \%$ \\
\hline Емпієма при легеневому туберкульозі & 203 & $57,8 \pm 1,3^{*}$ & 200 & $59,8 \pm 0,8^{*}$ \\
\hline Фібринозний плеврит & 76 & $21,6 \pm 2,5^{*}$ & 74 & $22,1 \pm 3,2^{*}$ \\
\hline Змішані & 44 & $12,5 \pm 0,3^{*}$ & 40 & $13,9 \pm 0,7^{*}$ \\
\hline Післяопераційні & 28 & $7,9 \pm 1,7^{*}$ & 20 & $5,9 \pm 2,1^{*}$ \\
\hline Бронхіальні фістули & 41 & $11,6 \pm 2,3^{*}$ & 30 & $8,9 \pm 1,8^{*}$ \\
\hline Всього & 351 & $100 \% *$ & 334 & $100 \% *$ \\
\hline
\end{tabular}

Примітка. * - достовірна різниця між групами $(p<0,05)$.

У більшості випадків туберкульозної емпієми плеври -у 57,8 \% - спостерігалося поява вторинної емпієми при легеневому туберкульозі, у 21,6 \% випадків емпієма розвинулася самостійно при туберкульозному плевриті. Бронхіальні фістули діагнос- тували у 11,7 \% випадків туберкульозної емпієми плеври. У пацієнтів із гострою емпіємою плеври тривалість захворювання склала не більше 1-2 місяців. Розподіл хворих залежно від часу виявлення нагноєння представлено в таблиці 5.

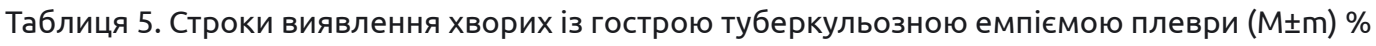

\begin{tabular}{|c|c|c|c|c|}
\hline \multirow{2}{*}{$\begin{array}{c}\text { Строки } \\
\text { захворювання }\end{array}$} & \multicolumn{2}{|c|}{ Основна група } & \multicolumn{2}{|c|}{ Група порівняння } \\
\hline & a6c. & $(M \pm m) \%$ & a6c. & $(M \pm m) \%$ \\
\hline 1 тиждень & 11 & $3,1 \pm 0,3 *$ & 14 & $4,1 \pm 0,7$ * \\
\hline 2 тижні & 34 & $9,6 \pm 1,9 *$ & 35 & $10,4 \pm 3,1$ * \\
\hline 3 тижні & 75 & $21,3 \pm 2,6 *$ & 85 & $25,4 \pm 3,1 *$ \\
\hline 4 тижні & 146 & $41,5 \pm 2,7 *$ & 125 & $37,3 \pm 2,3 *$ \\
\hline 2 місяці & 70 & $19,9 \pm 1,6^{*}$ & 62 & $18,5 \pm 2,1$ * \\
\hline 3 місяці & 15 & $4,2 \pm 0,7^{*}$ & 13 & $3,8 \pm 3,2 *$ \\
\hline Всього & 351 & $100 \% *$ & 334 & $100 \%$ * \\
\hline
\end{tabular}

Примітка. *- достовірна різниця між групами $(\mathrm{p}<0,05)$.

Отримані дані дозволяють зробити висновок, що найбільша кількість пацієнтів була госпіталізована в строки від 3 тижнів до 1 місяція захворювання (основна група - 62,8 \%, порів- няльна група - 62,7 \%). Строки госпіталізації пацієнтів із хронічною туберкульозною емпіємою плеври наведено в таблиці 6.

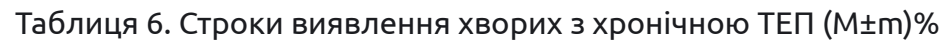

\begin{tabular}{|c|c|c|c|c|}
\hline \multirow{2}{*}{$\begin{array}{c}\text { Строки } \\
\text { захворювання }\end{array}$} & \multicolumn{2}{|c|}{ Основна група } & \multicolumn{2}{|c|}{ Група порівняння } \\
\hline & a6c. & $(M \pm m) \%$ & a6c. & $(M \pm m) \%$ \\
\hline 4 місяці & 25 & $50,0 \pm 1,1^{*}$ & 24 & $48,0 \pm 1,7 *$ \\
\hline 5 місяців & 24 & $48,0 \pm 1,7 *$ & 23 & $46,0 \pm 1,1^{*}$ \\
\hline 6 місяців і більше & 1 & $2,0 \pm 0,6 *$ & 3 & $6,0 \pm 0,3 *$ \\
\hline Всього & 50 & $100 \% *$ & 50 & $100 \% *$ \\
\hline
\end{tabular}

Примітка. * - достовірна різниця між групами (p>0,05).

Строки госпіталізації вказують на необхідність покращення діагностики та швидшого переведення таких пацієнтів у спеціалізовані хірургічні відділення. Розподіл хворих на туберкульозну емпієму плеври залежно від локалізації процесу наведено в таблиці 7.

У наших дослідженнях в обох групах переважали хворі із правобічною локалізацією туберку- 
Огляди літератури, оригінальні дослідження, погляд на проблему, випадок з практики, короткі повідомлення

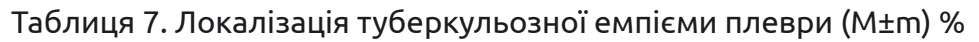

\begin{tabular}{|l|c|c|c|c|}
\hline \multirow{2}{*}{ Локалізація процесу } & \multicolumn{2}{|c|}{ Основна група } & \multicolumn{2}{c|}{ Група порівняння } \\
\cline { 2 - 5 } & а6с. & $(\mathrm{M} \pm \mathrm{m}) \%$ & $\mathrm{a} 6 \mathrm{c}$ & $(\mathrm{M} \pm \mathrm{m}) \%$ \\
\hline Правобічна & 230 & $65,5 \pm 2,3^{*}$ & 236 & $56,1 \pm 3,2^{*}$ \\
\hline Лівобічна & 92 & $26,2 \pm 1,6^{*}$ & 86 & $42,1 \pm 2,3^{*}$ \\
\hline Двобічна & 29 & $8,2 \pm 0,6^{*}$ & 12 & $1,8 \pm 0,3^{*}$ \\
\hline Всього & 351 & $100 \% *$ & 334 & $100 \% *$ \\
\hline Р & \multicolumn{3}{|c|}{$\mathrm{p}<0,05$} \\
\hline
\end{tabular}

Примітка: * - достовірна різниця між групами (p<0,05).

льозної емпієми плеври. Характеристики груп хворих, що вивчалися, дозволили зробити висновки, що пацієнти основної та порівняльної груп достатньо близькі за наведеними параметрами і дозволило в подальшому об'єктивно порівнювати результати діагностики та лікування.

При обстеженні хворих на туберкульозну емпієму плеври ретельне вивчення скарг дозволило запідозрити появу гнійного процесу лише у $474(69,2 \pm 2,9$ \%) пацієнтів (р<0,05). У решти хворих скарги були відсутні або мали незначне клінічне значення. Відмічалася переважно поява болю в грудній клітці або його стійке посилення протягом тривалого часу (не менше 2-3 тижнів) у 175 (25,6士2,3 \%) пацієнтів; зниження маси тіла більше ніж на 2-5 кг протягом 1-2 місяців - у 70 $(10,2 \pm 3,1 \%) ;$ поява а6о посилення задухи - у 60 $(8,9 \pm 2,5 \%) ;$ кашльовий синдром з посиленням болю в грудній клітці - у 44 (6,4士3,9 \%); осиплість

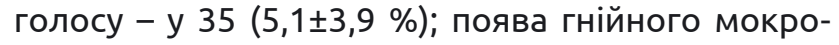

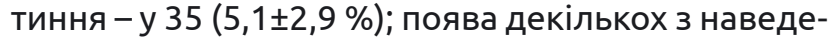
них скарг одночасно - у $52(7,7 \pm 2,3$ \%) $(p<0,05)$.

у більшості випадків останні з перерахованих симптомів з'являлися вже в хронічній стадії нагноєння плеври та були обумовлені його значною розповсюдженістю по плеврі (з появою гнійно-резорбтивної лихоманки, задухи та больового синдрому), ураженням гортанного нерва (осиплість голосу), напливних абсцесів навколишніх тканин, появою бронхіальної чи торакальної нориці тощо.

3 вищенаведеного можна зробити висновок, що скарги не $\epsilon$ важливим діагностичним алгорит- мом для ранньої діагностики туберкульозного нагноєння плеври та часто з'являються вже на пізніх стадіях перебігу.

Фізикальне обстеження пацієнтів також не мало суттєвої діагностичної цінності, у більшості пацієнтів суттєвих змін не виявлено. Лише у 210 $(30,7 \pm 2,1 \%)$ хворих були виявлені вірогідні зміни. Зміна характеру мокротиння на гнійне мала місце у 105 (15,4ะ3,9 \%) пацієнтів; відставання сторони ураження в акті дихання - у $44(6,4 \pm 3,9 \%)(p<0,05)$.

Тяжкість патологічних порушень білкового обміну була більше виражена у пацієнтів з хронічною туберкульозною емпіємою плеври. Відмічено ще більший приріст рівня альфа, -, альфа, -глобулінів $(17,92 \pm 0,56) \%,(p<0,01)$ та $(8,0 \pm 0,42) \%(p<0,01)$ відповідно. Ці зміни виявлялися на фоні гіпопротеїнемії - $(54,2 \pm 1,3)$ г/л, $(p<0,01)$ та альбумінемії $(36,7 \pm 0,8) \%,(p<0,01)$ відповідно, а інтегрований коефіцієнт А/Г знижувався - $(0,74 \pm 0,02)(p<0,01)$.

Тобто, порушення білкового обміну мало місце у всіх хворих з гострою та хронічною туберкульозною емпіємою плеври, при цьому більш виражені зміни виявлено у пацієнтів із хронічною емпіємою плеври. В проведених дослідженнях відмічено взаємозв'язок порушення функції печінки та білкового обміну. Зниження рівня білків відбувається внаслідок їх втрати із гнійним плевральним вмістом. При туберкульозній емпіємі плеври відбуваються досить значні зміни в імунологічному статусі пацієнтів. Ці імунологічні дослідження пацієнтів групи порівняння наведено в таблиці 8.

Таблиця 8. Зміни показників імунітету при туберкульозній емпіємі плеври

\begin{tabular}{|c|c|c|c|}
\hline Показники & $\begin{array}{c}\text { Гостра емпієма плеври } \\
\text { n=284 }\end{array}$ & $\begin{array}{c}\text { Хронічна емпієма плеври } \\
n=50\end{array}$ & $\mathrm{P}$ \\
\hline Т-лімфоцити, CD3 \pm , \% & $44,50 \pm 3,40$ & $41,20 \pm 0,90$ & $\mathrm{P}<0,01$ \\
\hline Т-хелпери, CD4士, \% & $35,30 \pm 1,20$ & $29,80 \pm 1,30$ & $\mathrm{P}<0,01$ \\
\hline Т-супресори, CD8ะ, \% & $17,20 \pm 2,25$ & $18,60 \pm 1,85$ & $P<0,01$ \\
\hline CD4 $\pm / C D 8 \pm$ & $2,06 \pm 0,05$ & $1,60 \pm 0,08$ & $\mathrm{P}<0,01$ \\
\hline В-лімфоцити, CD22士, \% & $18,40 \pm 4,60$ & $22,30 \pm 3,20$ & $\mathrm{P}<0,01$ \\
\hline $\lg$ A, г/л & $1,60 \pm 0,20$ & $1,80 \pm 0,30$ & $\mathrm{P}<0,01$ \\
\hline $\lg \mathrm{M}, г / л$ & $1,03 \pm 0,10$ & $1,20 \pm 0,23$ & $\mathrm{P}<0,01$ \\
\hline $\lg G$, г/л & $12,80 \pm 1,40$ & $10,80 \pm 1,20$ & $P<0,01$ \\
\hline
\end{tabular}


Огляди літератури, оригінальні дослідження, погляд на проблему, випадок з практики, короткі повідомлення

Представлені дані вказують на необхідність динамічного контролю за лабораторними показниками під час всього курсу лікування та необхідність використання імунокоригуючої терапії перед операцією з приводу ТЕП.

При проведенні спіральної комп'ютерної томографії без контрастного підсилення вдалося виявити характерні ознаки нагноєння лише у 492 $(71,8 \pm 1,9 \%)$ пацієнтів $(p<0,05)$. При цьому візуалізація туберкульозу легень була можлива у 406 (59,8土 3,0 \%) хворих на туберкульозну емпієму плеври, вторинні ознаки піопневмотораксу лише - у 128 $(18,7 \pm 2,9 \%)(p<0,05)$. Характерна для туберкульозу неоднорідність потовщення плеври виявлена нами лише у 235 (34,3ะ2,3 \%) пацієнтів, а деструк-

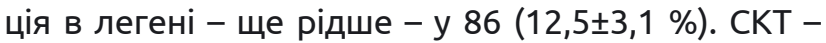
ознаки вогнищевої інфільтрації легені були чітко

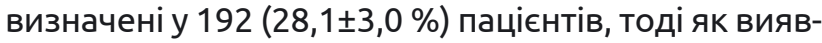
лення туберкульоми легень - лише у 42 (6,2ะ3,7\%). Інфільтративні зміни навкруги деструкції легень виявлялися на СКТ, при цьому їх було складно відрізнити від інфільтрації нетуберкульозного походження ( $<<0,05)$. Було проведено аналіз результатів СКТ до операції, порівняно з результатами інтраопераційної ревізії з подальшою біопсією та патогістологічними дослідженнями (табл. 9).

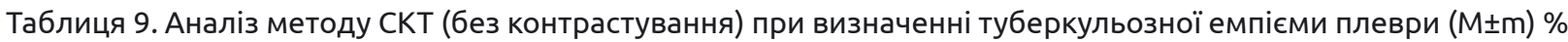

\begin{tabular}{|c|c|c|c|c|}
\hline \multirow{2}{*}{ Критерії діагностики } & \multicolumn{2}{|c|}{ Паріетальна та вісцеральна плевра } & \multicolumn{2}{|c|}{ Легенева тканина з бронхіолами } \\
\hline & a6c. & $(M \pm m) \%$ & a6c. & $(M \pm m) \%$ \\
\hline Чутливість, \% & 417 & $60,8 \pm 2,1^{*}$ & 287 & $41,9 \pm 0,8 *$ \\
\hline Специфічність, \% & 513 & $74,8 \pm 1,9 *$ & 438 & $63,9 \pm 2,3 *$ \\
\hline Точність, \% & 541 & $78,9 \pm 2,2 *$ & 465 & $67,8 \pm 2,6 *$ \\
\hline
\end{tabular}

Примітка. * - p - рівень значимості за критерієм $\chi^{2}$ Пірсона в основній групі та групі порівняння $(p<0,05)$.

3 вищенаведеного видно, що СКТ без контрастування не $\epsilon$ високочутливим методом у диференційній діагностиці туберкульозного нагноєння плеври. Діагностична цінність СКТ залежала від локалізації гнійного плевриту та активності туберкульозу. При локалізації емпієми в зоні туберкульозних змін чутливість методу не перевищувала 60 \%. На нашу думку, низька діагностична цінність СКТ при діагностиці туберкульозного ураження плеври та легеневої тканини пов'язана з неможливістю під час процедури відрізнити туберкульозне від нетуберкульозного ураження, а також від змішаних чи посттравматичних емпієм плеври.

Фібробронхоскопія з біопсією також не дає значних позитивних результатів під час ранньої діагностики туберкульозної емпієми плеври. Так, при проведенні фібробронхоскопії 605 хворим 3 емпіємою плеври внаслідок легеневого туберку-

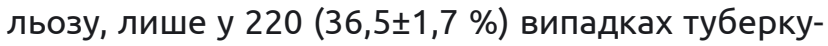
льозного ураження можливо було провести верифікацію діагнозу, при бронхіальній нориці лише у $19(3,1 \pm 0,9 \%)(p<0,05)$.

Цитологічне дослідження мокротиння, у тому числі при виконанні ФБС, не мало значної діагнос- тичної цінності та дозволило виявити МБТ клітини лише у 18,7 \% хворих на легеневий туберкульоз, ускладнений емпіємою плеври, та у 2,9 \% - при туберкульозному плевриті.

Із 685 хворих на туберкульозну емпієму плеври лише у 351 (51,2 \%) діагноз було вірогідно встановлено своєчасно та цим пацієнтам проведено малоінвазивне хірургічне лікування, яке склало основну групу даного наукового дослідження. У решти 334 (48,7 \%) пацієнтів емпієма плеври була визнана занедбаною та їм було виконано відкриту операцію плевректомії з декортикацією легені.

В усіх хворих обох груп спостереження обов'язковим було проведення патогістологічного дослідження біопсійного матеріалу, резектатів легені та ураженої плеври. Ми поділили всі клінічні випадки на 4 категорії, що представленні в таблиці 10:

1. Емпієма плеври на фоні легеневих туберкульозних змін.

2. Туберкульозний плеврит, ускладнений емпіємою плеври.

3. Змішані емпієми плеври.

4. Післяопераційні емпієми плеври.

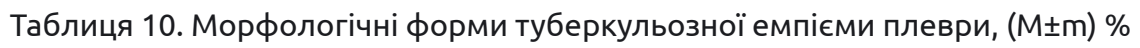

\begin{tabular}{|c|c|c|c|c|}
\hline \multirow{2}{*}{ Морфологічні форми } & \multicolumn{2}{|c|}{ Основна група(n=351) } & \multicolumn{2}{|c|}{ Група порівняння (n=334) } \\
\hline & a6c. & $(\mathrm{M} \pm \mathrm{m}) \%$ & a6c. & $(M \pm m) \%$ \\
\hline 1 & 2 & 3 & 4 & 5 \\
\hline Емпієма при туберкульозі & 203 & $57,4 \pm 2,6 *$ & 200 & $59,6 \pm 1,8^{*}$ \\
\hline Потовщення плеври & 65 & $18,5 \pm 2,2 *$ & 26 & $7,7 \pm 2,7^{*}$ \\
\hline Лімфангіїт плеври & 36 & $10,2 \pm 0,1 *$ & 17 & $5,1 \pm 0,6^{*}$ \\
\hline
\end{tabular}


Огляди літератури, оригінальні дослідження, погляд на проблему, випадок з практики, короткі повідомлення

Продовження табл. 10

\begin{tabular}{|l|c|c|c|c|}
\hline \multicolumn{1}{|c|}{1} & 2 & 3 & 4 & 5 \\
\hline Міліарні горбики & 40 & $11,3 \pm 1,0^{*}$ & 33 & $9,8 \pm 3,2^{*}$ \\
\hline Казеозні виразки, некрози & 28 & $7,9 \pm 3,6^{*}$ & 30 & $8,9 \pm 3,2^{*}$ \\
\hline Гіалінізація плеври, фіброз & 24 & $6,8 \pm 5,2^{*}$ & 47 & $14,1 \pm 2,4^{*}$ \\
\hline Бронхолегеневі фістули & 7 & $1,9 \pm 2,9^{*}$ & 43 & $12,8 \pm 3,9^{*}$ \\
\hline Плевроторакальні нориці & 3 & $0,8 \pm 1,3^{*}$ & 4 & $1,2 \pm 0,9^{*}$ \\
\hline $\begin{array}{l}\text { Туберкульозний плеврит, } \\
\text { ускладнений емпіємою }\end{array}$ & 76 & $21,6 \pm 2,1^{*}$ & 74 & $22,1 \pm 2,3^{*}$ \\
\hline Змішані емпієми плеври & 44 & $12,5 \pm 2,6^{*}$ & 40 & $11,9 \pm 1,8^{*}$ \\
\hline Післяопераційні емпієми & 28 & $7,9 \pm 3,2^{*}$ & 20 & $5,9 \pm 0,6^{*}$ \\
\hline
\end{tabular}

Примітка. * - p - рівень значимості за критерієм $\chi^{2}$ Пірсона в основній групі та групі порівняння $(p<0,05)$.

Цитологічне дослідження. Альвеолоцити I типу та ендотеліоцити кровоносних капілярів плеври мали ознаки внутрішньоклітинного набряку. Цитоплазма їх містила невелику кількість рибосом та полісом, мала зруйновані кристи. Траплялися мітохондрії зі зруйнованими зовнішними мембранами. У відростках альвеолоцитів I типу та ендотеліоцитів кровоносних капілярів практично були відсутні мікропіноцитозні бульбашки. Мезотеліальні клітини мали деструктивні зміни. Але при високій вірулентності мікобактерій туберкульозу в рідині дуже швидко приєднувалася вірулентна грамнегативна флора, і ексудат переходив із серозного в гнійний. Санація з активним пункційним очищенням емпіємної порожнини та санація 3 плевросорбцією істотно стимулювала репаративні процеси альвеолоцитів II типу. Підтвердженням цього $\epsilon$ гіперплазія мембран гранулярної ендоплазматичної сітки. Знижується рівень вираження мітохондріальної дисфункції, з'являються поділені форми мітохондрій. Активуються репаративні внутрішньоклітинні процеси, що підтверджується гіперплазією мембран гранулярного ендоплазматичного ретикулуму. Альвеолярні макрофаги знаходяться в метаболічно активному стані. Мезотеліальні клітини мали ознаки відновлення їх субмікроскопічної організації (дуже рідко з'являються осередки лізису каріолеми, збільшується кількість рибосом та полісом, зменшується набряк мітохондрій, цитоплазматична мембрана потовщена та розпушена). Морфологічні зміни при ТЕП значно відрізняються від туберкульозних плевритів значним потовщенням парієтальної плеври (до 3-5 см) за рахунок новоутворених колагенових волокон, гіалінізації фіброцитів та фібробластів. У ній виявляються епітеліоїдні горбики із гігантськими клітинами Пирогова-Ланганса.

Гістологічне дослідження. Патогістологічна картина туберкульозу плеври може мати різноманітні морфологічні прояви: від тотального симетричного висипання міліарних горбиків у вигляді «посипаного піску» до обмеженого висипання по міжчастковій плеврі, або повна відсутність висипань. Обмеженість висипання міліарних горбиків по міжчастковій плеврі свідчить про лімфогенний шлях проникнення туберкульозу із легень у плевру, так званий туберкульозний лімфангіїт плеври. Значно рідше на плеврі спостерігаються казеозносирнисті вогнища, які, власне, й призводять до нагноєння в плеврі, яке згодом переходить у хронічну стадію. Зміни туберкульозного процесу були малими (потовщення плеври, лімфангіїт плеври, міліарні горбики, петрифікати) - у 143 (42,8 \%) обстежених та великими у 191 (57,1\%) - у вигляді грубого поширеного фіброзу (цирозу, склеротичних змін, казеозно-сирнистих виразок, конгломератів вогнищ, бронхолегеневих фістул, плевроторакальних нориць). Розташування вогнищево-інфільтративних туберкульозних змін виявлено переважно в верхніх частках легень.

Легеневий туберкульоз активно впливає на оперативне лікування хворих з туберкульозною емпіємою плеври. При лікуванні туберкульозної емпієми плеври 334 хворих групи порівняння найчастіше використовували задньобокову торакотомію. Ревізія плевральної порожнини ускладнювалась наявністю плевральних зрощень і змін у плеврі та міжчастковій легеневій тканині, що виникли на фоні туберкульозної інфекції чи перенесеного туберкульозного плевриту. Розділення зрощень збільшувало час оперативного втручання та інтраопераційну крововтрату, утруднювало мобілізацію кореня легені та ревізію середостіння. В групі порівняння плевральна порожнина була повністю облітерована у 80,2 \% хворих, частково облітерована у 17,2 \%. В 77,6 \% випадків спостерігали множинні міжчасткові плевральні зрощення, одиничні міжчасткові - в 9,8\%.

У 79 \% випадків для виділення легені із зрощень застосували екстраплевральний пневмоліз. У 21 \% випадків оперовану легеню виділяли із спайок інтраплеврально. У 11 \% хворих спостерігали розвиток бронхіальних нориць. У цих випадках У плевральній порожнині виникали масивні рубцеві 
Огляди літератури, оригінальні дослідження, погляд на проблему, випадок з практики, короткі повідомлення спайки, які було дуже складно розділити без крововтрати. При цьому об'єм інтраопераційної крововтрати під час пневмолізу до елементів кореня легені складав в середньому $(1052,8 \pm 63,4)$ мл. 17 хворим групи порівняння виконана декортикація 3 крайовою резекцією нориць із середнім об'ємом інтраопераційної крововтрати $(639,8 \pm 27,3)$ мл $(p>0,05)$.

У групі порівняння в ранньому післяопераційному періоді померло 2 (0,6 \%) хворих унаслідок тромбоемболії легеневої артерії та післяопераційної емпієми плеври з бронхіальною норицею. у 2 випадках була потрібна реторакотомія у зв'язку з формуванням гемотораксу, що згорнувся в післяопераційному періоді. У одному випадку в зв'язку зі сповільненим розправленням легені й формуванням залишкової порожнини було потрібне виконання повторної торакоскопії з додатковим дренуванням.

При ретроспективному аналізі 334 операцій (плевректомія з декортикацією легені) у хворих на туберкульозну емпієму плеври привертає увагу висока питома вага інтраопераційних (19,8 \%) та післяопераційних ускладнень (26,4%) при виконанні оперативних втручань з використанням стандартної задньобокової торакотомії.

\section{ЛІТЕРАТУРА}

1. Эмпиемы плевры. Оперативные методы лечения. Часть III [Текст] / Е. А. Цеймах [и др.] // Туберкулез и болезни легких : ежемес. науч.-практ. журн. - 2010. № 2. - С. 5-12.

2. Применение ранней видеоторакоскопической декортикации легкого в лечении острой эмпиемы плевры и нагноившегося свернувшегося гемоторакса [Текст] / П. П. Шипулин [и др.] // Клініч. хірургія : науково-практичний журнал. - 2010. - № 10. . - С. 29-31.

3. Кариев Т. М. Эффективность плеврэктомии при туберкулезной эмпиеме плевры [Текст] / Т. М. Кариев, Ш. Ю. Сабиров // Туберкулез и болезни легких : ежемес. науч.-практ. журн. - 2010. - № 12. - С. 29-30.

4. Опанасенко М. С. Ендоскопічні методи лікування підгострих і хронічних запальних захворювань плеври [Текст ] / М. С. Опанасенко, С. М. Шалагай, Е. В. Климець // Клініч. хірургія : науково-практичний журнал. 2017. - № 1. - С. 39-42.

5. Дужий І. Д. Питання епідеміології емпієми плеври [Текст] / І. Д. Дужий, І. Я. Гресько, Ю. О. Міщенко// Укр. Пульмон. Журнал: науково-практичний журнал. 2016. - № 3. - С. 60-63.

6. Применение эндобронхиального резинового клапана «Medlung» у пациента с хронической эмпиемой плевры и бронхоплевральными свищами / В. Е. Севергин [и др.] // Клініч. хірургія : Науково-практичний журнал. -2011 . - № 4. - С. 71-72.

7. Опанасенко М. С. Обгрунтування ефективності використання відеоасистованого доступу в хірургії запальних процесів плеври / М. С. Опанасенко, С. М. Шалагай, Е.В. Климець // Клініч. хірургія: Науково-практичний журнал. - 2017. - № 7. - С. 37-40.

8. Хирургическое лечение посттравматической эмпиемы плевры / Ш. Н. Даниелян [и др.] // Хирургия им. Н. И. Пирогова : науч.-практ. журн. - 2012. - № 3. - С. 4-10.

9. Симонец Е. Н. Профилактика гнойно-воспалительных осложнений грудной стенки у больных с острой эмпиемой плевры / Е. Н. Симонец, В. В. Макаров, А. Н. Шкурат // Запорож. мед. журн : науч.-практ. журн. 2012. - № 6. - С. 38-41.

10. Бойко В. В. Лечебная тактика у больных с многокамерной эмпиемой плевры / В. В. Бойко, В. В. Макаров, В. Г. Грома // Вісн. невідкладної і відновної медицини : науково-практичний журнал. - 2012. - Т. 13, № 3. - С. 327-330.

11. Шаров Ю. К. Empyema necessitatis / Ю. К. Шаров, И. А. Ларин, А. Ю. Литвинов // Вестн. хирургии им. И. И. Грекова : научно-практический журнал. - 2013. T. 172, № 2. - C. 57-59.

12. Surgery and pleuro-pulmonary tuberculosis: a scientific literature review / D. Subotic, P. Yablonskiy, G. Sulis [et al.] // J. Thorac. Dis. - 2016. - Vol. 8 (7). - P. E474-E485.

13. Porcel J. M. Tuberculous pleural effusion / J. M. Porcel // Lung. - 2009. - Vol. 187. - P. 263-270.

14. Revisiting tuberculous pleurisy: pleural fluid characteristics and diagnostic yield of mycobacterial culture in an endemic area / S. Y. Ruan, Y. C. Chuang, J. Y. Wang [et al.] // Thorax. - 2012. - Vol. 67. - P. 822-827.

15. Subotic D. Minimally invasive thoracic surgery for empyema / D. Subotic, D. Lardines, A. Hojski // Breathe December. - 2018. - Vol. 14 (4). - P. 302-319.

16. Pleural tuberculosis in the United States: incidence and drug resistance / M. H. Baumann, R. Nolan, M. Petrini [et al.] // Chest. - 2007. - Vol. 131. - P. 1125-1132. 
Огляди літератури, оригінальні дослідження, погляд на проблему, випадок з практики, короткі повідомлення REFERENCES

1. Ceimach, E.A. (2010). Empiema pleuri. Operativni metody lecheniya. Chast III [Empyema of pleura. Surgical treatment methods. Part III]. Tuberkuloz i bolezni legkikh Tuberculosis and Lung Diseases, 2, 5-12 [in Russian].

2. Shipulin, P.P. (2010). Primeneniya raniy dekortikatsii legkogo $v$ lechenii ostroy empiemy pleuri i nagnoivshegosya svernutogo gemotoraksa [The use of early videothoracoscopic lung decortication in the treatment of acute empyema of the pleura and suppurating clotted hemothorax]. Klinichna khirurhiia - Clinical Surgery, 10, 29-31 [in Russian].

3. Kariev, T.M., \& Sabirov, Sh.Y. (2010). Efektivnost pleurektomii pri tuberkuloznoy empieme pleury [The effectiveness of pleurectomy in tuberculous pleural empyema]. Tuberkulos i bolezni legkikh - Tuberculosis and Lung Diseases, 12, 29-30 [in Russian].

4. Opanasenko, M.S., Shalahay, S.M., \& Klymets, E.V. (2017). Endoskopichni metody likuvannia pidhostrykh i khronichnykh zapalnykh zakhvoriuvan pleury [Endoscopic methods of treatment of subacute and chronic inflammatory diseases of the pleura]. Klinichna khirurhiia - Clinical Surgery, 1, 39-42 [in Ukrainian].

5. Duzhii, I.D. (Ed). (2016). Pytannia epidemiolohii empiemy pleury [Issues of epidemiology of pleural empyema]. Ukrainskyi pulmonolohichnyi zhurnal - Ukrainian Pulmonogy Journal, 3, 60-63 [in Ukrainian].

6. Severgin, V.E. (Ed). (2011). Primineniya endobronkhialnogo rezinevogo klapana "Medlung" u patsientov s khronicheskoy empiemoy pleury i bronkhopleuralnimi svizhami [The use of the Medlung endobronchial rubber valve in a patient with chronic pleural empyema and bronchopleural fistula]. Klinichna khirurhiia-Clinical Surgery, 4, 71-72 [in Ukrainian].

7. Opanasenko, M.S., Shalahai, S.M., \& Klymets, E.V. (2017). Obhruntuvannia efektyvnosti vykorystannia videoasystovanoho dostupu v khirurhii zapalnykh protsesiv pleury [Substantiation of the efficiency of the use of video-as-

sisted access in surgery of inflammatory processes of the pleura]. Klinichna khirurhiia - Clinical Surgery, 7, 37-40 [in Ukrainian].

8. Danielyan, Zh.N. (Ed). (2012). Khirurgicheskoe lechenie posttravmaticheskoy empiemy pleuri [Surgical treatment of post-traumatic pleural empyema]. Khirurgiya imeni N.I. Grekova - Surgery named after N.I. Grekov, 3, 4-10 [in Russian].

9. Simonets, E.N., Makarov, V.V., \& Zhkurat, A.N. (2012). Profilaktika gnoyno-vospalitelnykh oslozhneniy grudnoy stinky u bolnikh s ostroy empiemoy pleury [Prevention of purulent-inflammatory complications of the chest wall in patients with acute pleural empyema]. Zaporozhkiy med. zhurn. - Zaporozhian Medical Jornal, 6, 38-41 [in Ukrainian].

10. Boyko, V.V., (Ed). (2012). Lechebnaya taktika u bolnykh s mnogokamernoy empiemoy pleury [Therapeutic tactics in patients with multichamber pleural empyema]. Visnyk nevidkladnoi $i$ vidnovnoi medytsyny - Bulletin of emergency and Recovery Medicine, 13, 3, 327-330 [in Ukrainian].

11. Zharov, Y.K. (Ed). (2013). Empyema necessitates. Khirurhiia imeni N. I. Hrekova - Surgery named after N.I. Hrekov, 172, 2, 57-59.

12. Subotic, D., Yablonskiy, P., \& Sulis, G. (2016). Surgery and pleuro-pulmonary tuberculosis: a scientific literature review. J. Thorac. Dis., 8 (7), E474-E485.

13. Porcel, J.M. (2009). Tuberculous pleural effusion. Lung, 187, 263-70.

14. Ruan, S.Y., Chuang, Y.C., \& Wang, J.Y. (2012). Revisiting tuberculous pleurisy: pleural fluid characteristics and diagnostic yield of mycobacterial culture in an endemic area. Thorax, 67, 822-827.

15. Subotic, D., Lardines, D., \& Hojski, A. (2018). Minimally invasive thoracic surgery for empyema. Breathe December, 14 (4), 302-319.

16. Baumann, M.H., Nolan, R., \& Petrini, M. (2007). Pleural tuberculosis in the United States: incidence and drug resistance. Chest, 131, 1125-1132.

\title{
АНАЛИЗ ХИРУРГИЧЕСКОГО ЛЕЧЕНИЯ БОЛЬНЫХ ТУБЕРКУЛЕЗНОЙ ЭМПИЕМОЙ ПЛЕВРЫ
}

๑ю. Ф. Кошак

\author{
Тернопольский национальный медицинский университет имени И. Я. Горбачевского мОз Украины
}

РЕЗЮМЕ. Цель - улучшить результаты малоинвазивного хирургического лечения больных с туберкулезной эмпиемой плевры.

Материал и методы. Проведен ретроспективный анализ 685 случаев туберкулезной эмпиемы плевры у пациентов, которые за последние 10 лет прошли стационарное лечение во фтизиохирургическом отделении Тернопольского областного противотуберкулезного диспансера. Всем больным были проведены необходимые клинические, лабораторные и инструментальные исследования, включая рентгенологические и иммунологические методы обследования.

Результаты. Представлен первый в Украине анализ результатов хирургического лечения больных туберкулезной эмпиемой плевры в зависимости от применения стандартных диагностических и хирургических методик. Проанализированы морфологические особенности стадийности, локализации и диагностики туберкулезной эмпиемы плевры в зависимости от пола, возраста, начала, течения и распространенности нагноения. Анализ диагностической ценности стандартных методов диагностики туберкулезного нагноения у больных туберкулезом показал, что своевременное выявление такого осложнения значительно затруднено. Наибольшие диагностические трудности случаются у пациентов с локализацией эмпиемы плевры в зоне активных туберкулезных или метатуберкулезных изменений. 
Огляди літератури, оригінальні дослідження, погляд на проблему, випадок з практики, короткі повідомлення

Выводы. Показаны ведущее влияние вида туберкулезного поражения плевры на оперативное лечение больных туберкулезной эмпиемой плевры и пути улучшения хирургических методик малоинвазивного торакохирургичного лечения.

КЛюЧЕВЫЕ СЛОВА: туберкулез; туберкулезная эмпиема плевры; видеоторакоскопия; видеоасистированная хирургическая резекция; открытая плеврэктомия с декортикацией легкого.

\section{ANALYSIS OF RESULTS OF SURGICAL TREATMENT OF PATIENTS WITH TUBERCULOUS PLEURAL EMPYEMA}

\section{Horbachevsky Ternopil National Medical University}

@Yu. F. Koshak

SUMMARY. The aim is to improve the results of minimally invasive surgical treatment of patients with tuberculous pleural empyema.

Material and Methods. A retrospective analysis of 685 cases of pleural tuberculosis in patients who underwent inpatient treatment in the Phthisiosurgical Unit of the Ternopil Regional TB Dispensary was conducted in the last 10 years. Necessary clinical, laboratory, and instrumental studies, including radiological and immunological examination methods, were performed for all patients.

Results and Discussion. The first in Ukraine analysis of the results of surgical treatment of patients with combined forms of pleural TB empyema with the use of standard diagnostic and surgical techniques is presented. The morphological features of stage, localization and diagnostics of pleural TB are analyzed depending on the gender, age, beginning, course and prevalence of suppuration. It is shown leading effect of pleural tuberculosis on the surgical treatment of patients with pleural TB empyema and ways will the improved surgical techniques for minimally invasive thoracic surgery (VTS, VATS) treatment.

Conclusions. The leading influence of the type of tuberculous lesion of the pleura on the operative treatment of patients with tuberculous pleural empyema and the ways of improvement of surgical methods to the minimally invasive thoracosurgical treatment are shown.

KEY WORDS: tuberculosis; tuberculosis empyema; videothorcoscopy; video-assisted surgical resection; open pleurectomy with decortication of the lungs. 